\title{
Experimental studies of mild steel corrosion inhibition in hydrochloric acid using inhibitor type sulfa drugs
}

\author{
Adiba A. Mahmmod \\ Department of Chemical Engineering - College of Engineering - University of Diyala - \\ Baquba City 32001, Daiyla governorate, Iraq \\ E-mail: alnuimiadiba@yahoo.com
}

\begin{abstract}
A corrosion inhibitor is a chemical compound that, when added to a gas or liquid, decreases the process of corrosion. Sulfaguanidine is a guanidine derivative of sulfanilamide antibiotic used in veterinary medicine, the gut but is well suited for the treatment of bacillary dysentery and other enteric infections and sulfonamides are active against Gram-positive bacteria and Gram-negative bacteria. In the present work I studied the effect of Sulfaguanidine (SFGD) type inhibitor on carbon steel corrosion in a corrosive medium $(\mathrm{HCl})$. For this, I used the weight loss measurements to evaluate the data of corrosion rate and the results showed that SFGD performed excellently as a corrosion inhibition of metal type carbon steel in hydrochloric acid environment. The inhibition of corrosion of the used metal in present work in corrosive solution $(3 \% \mathrm{HCl})$ at the temperature range of $\left(30-60^{\circ} \mathrm{C}\right)$ and $(0.002-0.008 \mathrm{M})$ was studied in the absence and presence of the SFGD inhibitor used in this experimental work. Corrosion rate decreased with an increase in inhibitor concentration, also it increased with an increase in temperature while the efficiency of inhibition increased with an increase in SFGD concentration. The efficiency reaches a maximal value of $97.61 \%$ at $0.008 \mathrm{M}$ at $30^{\circ} \mathrm{C}$. The adsorption isotherm of inhibitor on metal surface used in this research was found to follow Langmuir, the kinetic-thermodynamic data and adsorption isotherms were used to evaluate the values of equilibrium constants $(K)$.
\end{abstract}

Keywords: carbon steel, sulfa drugs inhibitor, adsorption, corrosive solution, weight loss technique.

Received: May 27, 2019. Published: December 9, 2019

doi: $\underline{10.17675 / 2305-6894-2019-8-4-18}$

\section{Introduction}

The profound process playing an active part in industry is corrosion, especially for alloys and metals. There are wide applications for mild or carbon steel in industries and petroleum applications, such as flow lines and down hole tubular [1-9]. Inhibitors of corrosion process represent enormous practical emphasis, being comprehensive employed in minimizing metallic waste and the inhibitor use is represent one of the best methods known of corrosion protection process in industrial field and the best way to resist corrosion growth [10-14]. Corrosive solutions such as $\mathrm{HCl}, \mathrm{H}_{2} \mathrm{SO}_{4}$ and $\mathrm{H}_{3} \mathrm{PO}_{4}$, which ample used in petroleum arena is hydrochloric acid, for descaling of steel alloys in 
addition hydrochloric acid solution represent one of the most corrosive environments as mention above hence, investigation corrosion inhibitors for metal type mild steel in $\mathrm{HCl}$ are important for its industrial meaning and its applications [15-17]. The utilization of inhibitors is one of the better methods defense or protection from corrosion $[18,20]$. Compounds used as type of organic inhibitors act efficient figure through a process of adsorption on the metal surface, when the inhibitors includes the number for adhesion active centers in the molecule itself, their charge density, the molecule size, the adhesion mode [21-23]. In present work the mild steel protection oppose corrosion can be seen by addition of chemical materials in little quantity to corrosive environment which define an inhibitor of corrosion. Therefore, this combating take place by using inhibitors of corrosion based on an organic compounds containing in their structural nitrogen, sulphur and oxygen atoms functional groups [24-25]. The purpose of the present work was to study the effect of concentration of inhibitor and temperature of corrosive solution on the corrosion of carbon steel in the presence of SFGD as corrosion inhibitor. The chemical structure of SFGD inhibitor is shown below:

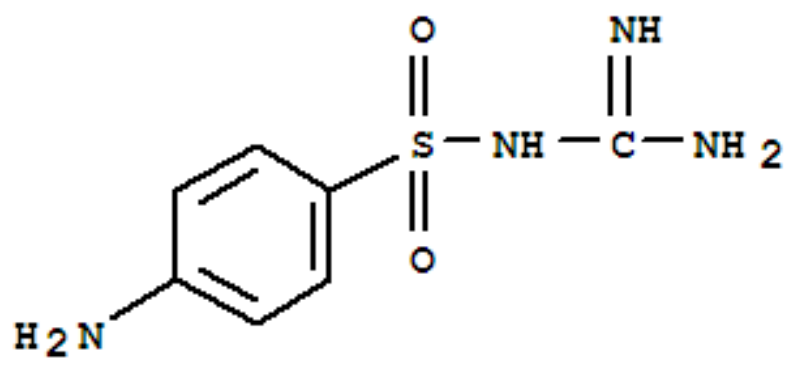

\section{Experimental work}

Runs of experimental were carried out in the absence and presence of inhibitor at variety values of temperature and concentration by using weight loss technique in $(0.002,0.004$, $0.006,0.008 \mathrm{M})$ as a concentrations of corrosion inhibitor type SFGD in corrosive solution $(3 \% \mathrm{HCl})$ at different temperature $\left(30,40,50\right.$, and $\left.60^{\circ} \mathrm{C}\right)$. The sample of carbon steel used in this research is a $2 \mathrm{~cm}^{2}$ exposure surface area. The chemical compositions (\% wt) of sample Fe: $99.25 \%$, Cr: $0.160 \%$, C: $0.14 \%, \mathrm{Mn}: 0.44 \%, \mathrm{Cu}: 0.146 \%$. The carbon steel sample was immersed in $100 \mathrm{~cm}^{3}$ acidic solution which placed in a glass flask, it was exposed for a time period of 6 hours. Weight losses data were determined in absence and presence of (SFGD), the corrosion rate units were $\left(\mathrm{mg} / \mathrm{cm}^{2} \cdot \mathrm{h}\right)$ in the present work.

\section{Results and discussion}

\subsection{Measurements of weight loss}

The values of corrosion rates of sample mentioned above in corrosive solution represented by $(3 \% \mathrm{HCl})$ as a temperature function without presence of (SFGD) and presence of 
diverse concentrations of inhibitor are listed in Table 1 using weight loss technique. The values of rates of corrosion were calculated using the following equation:

$$
\mathrm{CR}=W_{1}-W_{2} / A \times t
$$

Where CR is corrosion rate $\left(\mathrm{mg} / \mathrm{cm}^{2} \cdot \mathrm{h}\right), W_{1}$ and $W_{2}(\mathrm{mg})$ are the mass before and after submersion, $A$ represent is the total surface area of sample $\left(\mathrm{cm}^{2}\right)$, and $t$ mean the time of experiment (hours). While values of inhibitors efficiency were determined using the following equation:

$$
\% I E=\left(C_{\mathrm{R}}^{0}-C_{\mathrm{R}} / C_{\mathrm{R}}^{0}\right) \times 100
$$

Table 1 and Figure 1 reveal the alteration of the degree of corrosion with inhibitor concentration at different values of temperature. The addition of inhibitor reduces the rate of corrosion. Figures 2,3 represents the effect of temperature on the corrosion amount \& efficiency of the metal sample in erosive solution in presence of $0.008 \mathrm{~mol} / \mathrm{L} \&$ $0.002 \mathrm{~mol} / \mathrm{L}$ from inhibitor type SFGD, the degree of corrosion increases with temperature increasing and efficiency decreases with temperature increasing. Figure 4 represent the effect of inhibitor concentration of inhibitor on the efficiency and corrosion degree in corrosive solution at $30^{\circ} \mathrm{C}$, the efficiency increases with concentration increasing of SFGD.

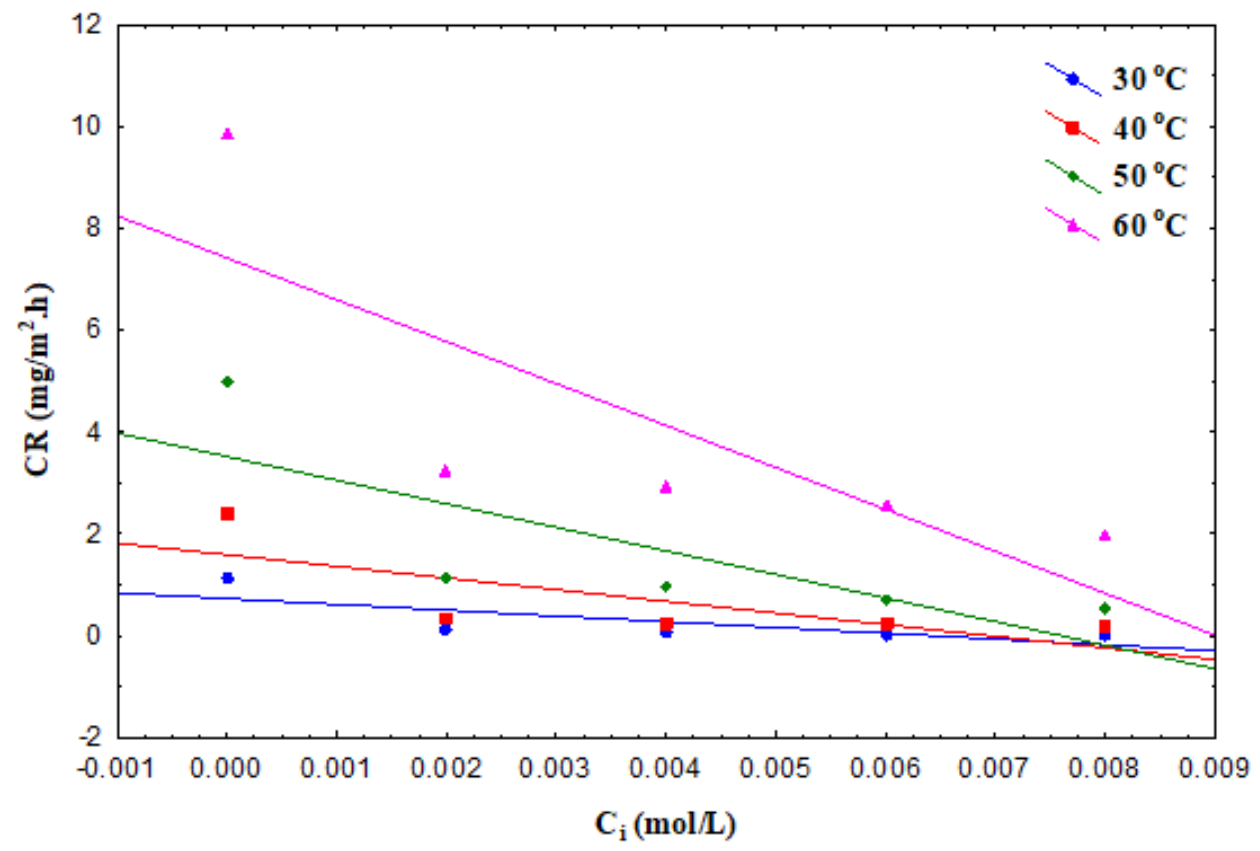

Figure 1. Effect of the concentration of sulfaguanidine on the corrosion rate of carbon steel in hydrochloric acid at different temperature. 
Table 1. Temperature effect and concentration of inhibitor on the corrosion process of metal sample in $3 \% \mathrm{HCl}$.

\begin{tabular}{|c|c|c|c|c|}
\hline Inhibitor Type & $\begin{array}{c}\text { Temp. } \\
\left({ }^{\circ} \mathrm{C}\right)\end{array}$ & $\begin{array}{c}\text { Conc. of inhibitor } \\
\text { (M) }\end{array}$ & $\begin{array}{l}\text { Corrosion rate } \\
\left(\mathrm{mg} / \mathrm{cm}^{2} \cdot \mathbf{h}\right)\end{array}$ & $\begin{array}{c}\text { Efficiency } \\
(\%)\end{array}$ \\
\hline \multirow{4}{*}{ Nil } & 30 & 0 & 1.129 & - \\
\hline & 40 & 0 & 2.39 & - \\
\hline & 50 & 0 & 4.98 & - \\
\hline & 60 & 0 & 9.880 & - \\
\hline \multirow{16}{*}{ SFGD } & \multirow{4}{*}{30} & 0.002 & 0.1087 & 90.37 \\
\hline & & 0.004 & 0.0593 & 94.74 \\
\hline & & 0.006 & 0.042 & 96.28 \\
\hline & & 0.008 & 0.0269 & 97.61 \\
\hline & \multirow{4}{*}{40} & 0.002 & 0.3515 & 85.29 \\
\hline & & 0.004 & 0.246 & 89.70 \\
\hline & & 0.006 & 0.2131 & 91.08 \\
\hline & & 0.008 & 0.1694 & 92.91 \\
\hline & \multirow{4}{*}{50} & 0.002 & 1.1209 & 77.49 \\
\hline & & 0.004 & 0.9486 & 80.95 \\
\hline & & 0.006 & 0.730 & 85.34 \\
\hline & & 0.008 & 0.544 & 89.07 \\
\hline & \multirow{4}{*}{60} & 0.002 & 3.2702 & 66.90 \\
\hline & & 0.004 & 2.926 & 70.38 \\
\hline & & 0.006 & 2.568 & 74.00 \\
\hline & & 0.008 & 1.9918 & 79.84 \\
\hline
\end{tabular}




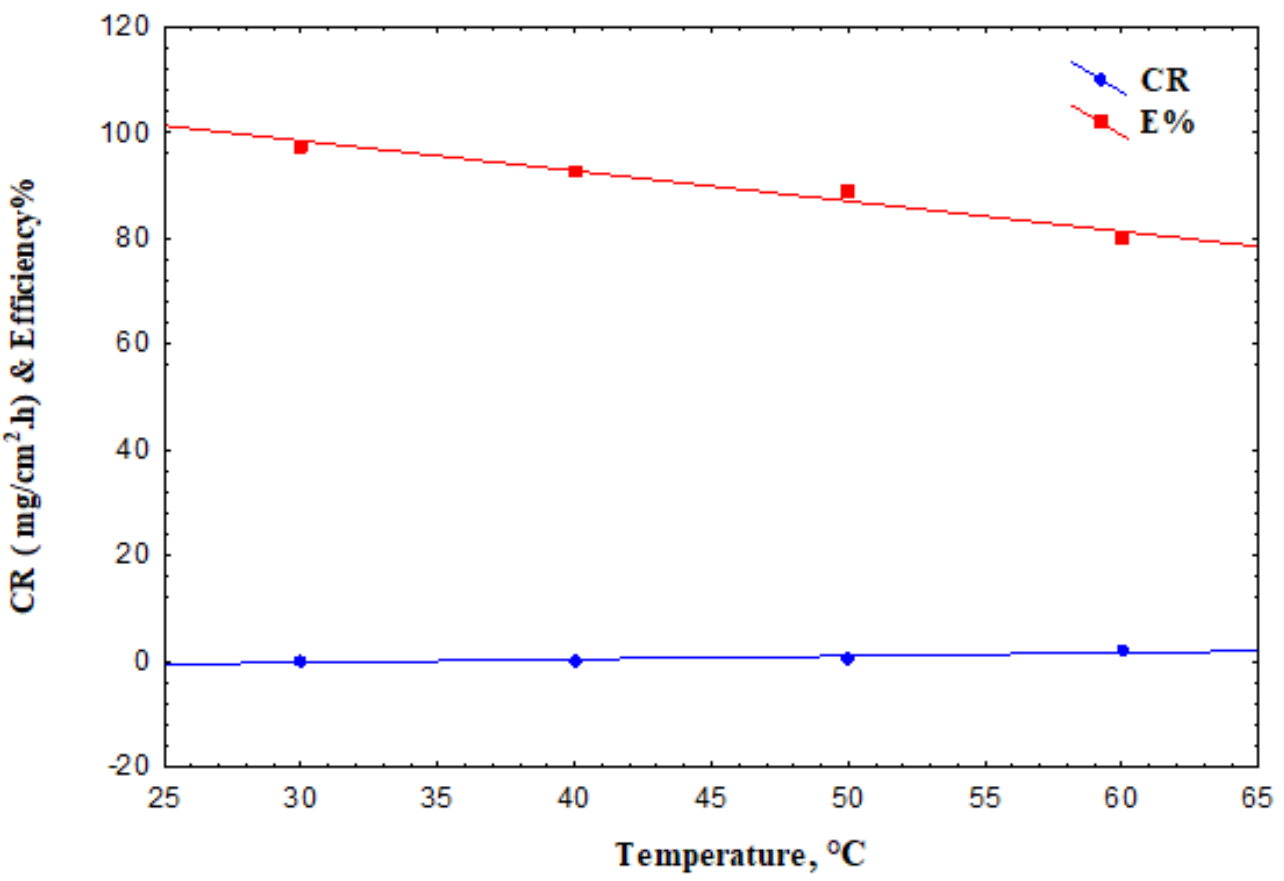

Figure 2. Effect of temperature on the corrosion rate \& efficiency of carbon steel in hydrochloric acid in presence of $0.008 \mathrm{~mol} / \mathrm{L}$ from sulfaguanidine.

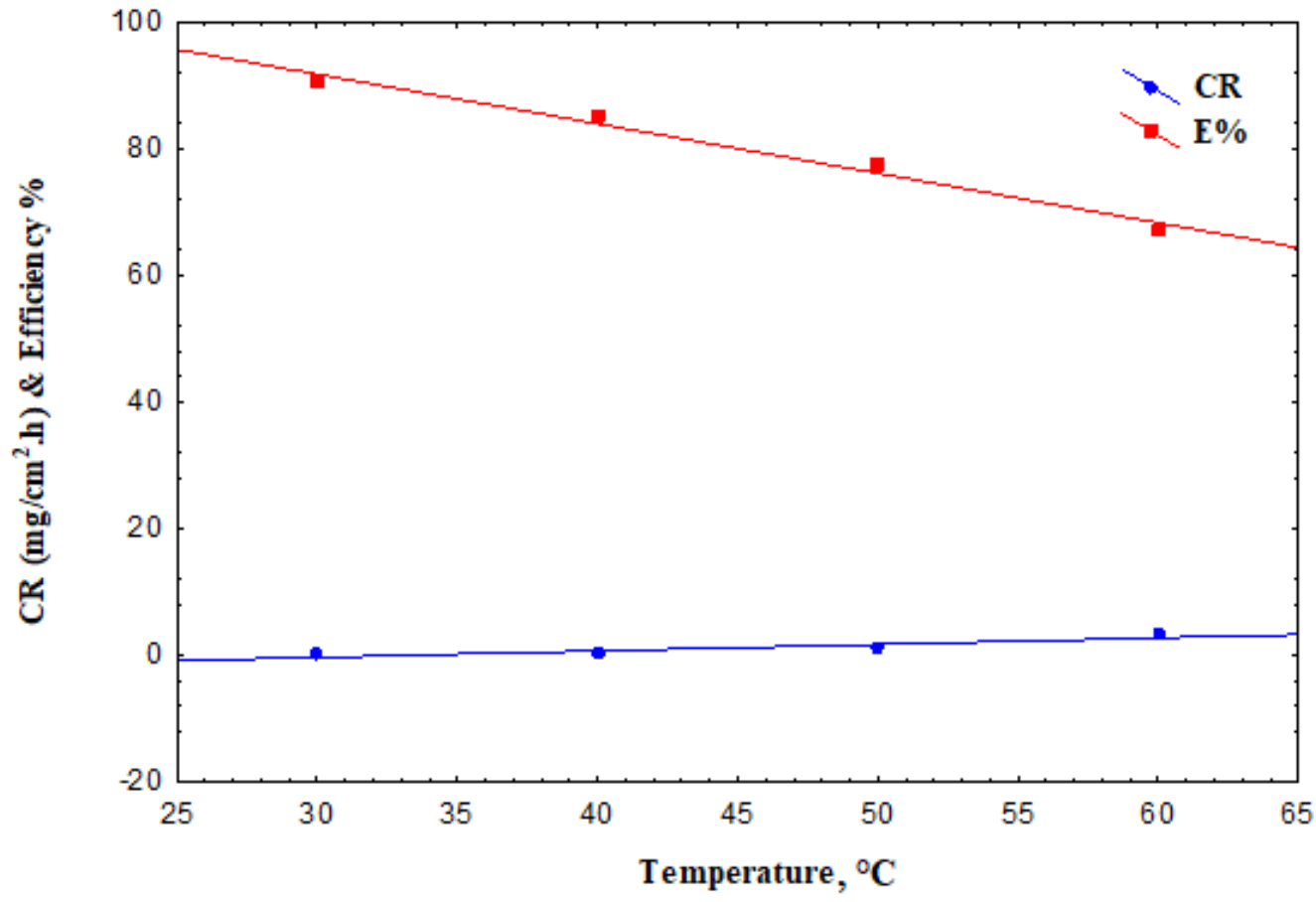

Figure 3. Effect of temperature on the corrosion rate \& efficiency of carbon steel in hydrochloric acid in presence of $0.002 \mathrm{~mol} / \mathrm{L}$ from sulfaguanidine. 


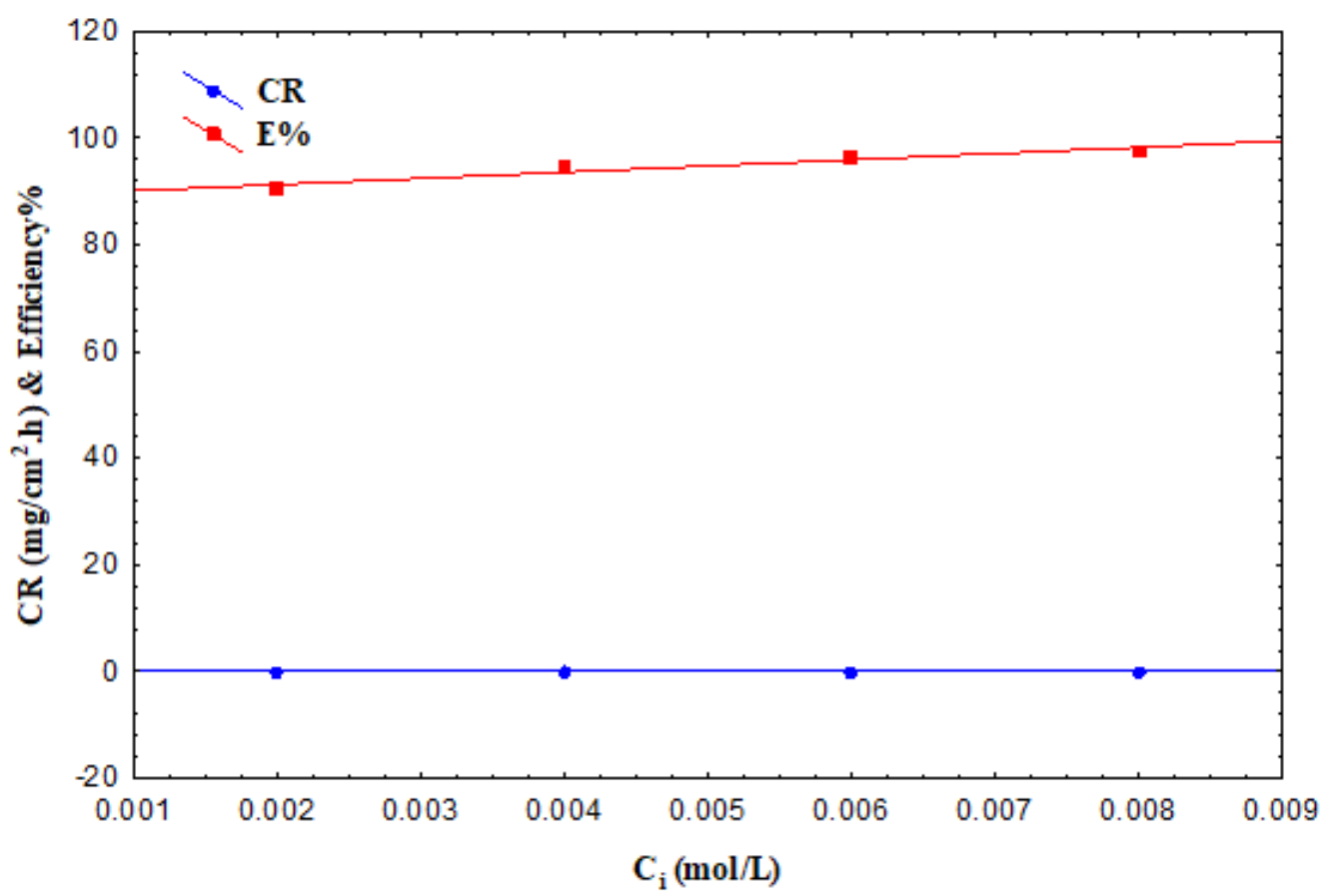

Figure 4. Effect of inhibitor concentration of sulfaguanidine on the corrosion rate \& efficiency of carbon steel in hydrochloric acid at $30^{\circ} \mathrm{C}$.

\subsection{Effect of temperature and parameters of thermodynamic}

In acidic solutions (evolution of hydrogen), the degree of corrosion rises exponentially with raising temperature $[22,23]$. Activation parameters for some systems perhaps predicted either from an Arrhenius equation (Eq. 3) [24-26].

$$
C_{\mathrm{R}}=A \exp \left(-E_{\mathrm{a}} / R T\right)
$$

The data of exposure coverage of metal sample surface $(\theta)$ are useful during studying the mechanism of adsorption. When the sample surface portion covered is evaluated as a function of the inhibitor concentration at invariant temperature, adsorption isotherm could be estimated at equilibrium circumstance. In present study three adsorption isotherms were used, Langmuir adsorption isotherm (Eq. 4), Freundlich adsorption isotherm (Eq. 5), and kinetics - thermodynamics isotherm (Eq. 6).

$$
\begin{gathered}
C / \theta=1 / K_{\mathrm{L}}+C \\
\ln \theta=\ln K_{\mathrm{F}}+n \ln C \\
\ln (\theta /(1-\theta))=\ln K^{\prime}+y \ln C
\end{gathered}
$$

$K_{\mathrm{L}}$ and $K_{\mathrm{F}}$ are the equilibrium constants of Langmuir adsorption isotherm and Freundlich adsorption isotherm. While $n$ is a power constant in Freundlich adsorption isotherm. In Eq. 6, $K^{\prime}$ is a constant, and $y$ expresses the number of inhibitor molecules filling one effective location. Values of $y>1$ mean that the multilayer formation process of inhibitor on the sample surface used in this work. Values of $y<1$ mean a given inhibitor 
molecules will occupy or fill more than one effective site. Equations 4-6 can be represented graphically as shown in Figures 5,6 and 7 for Langmuir, Freundlich adsorption, and kinetics-thermodynamics isotherms. Table 2 brings the adsorption parameters of thermodynamic for all mentioned above that got from graphical representations [27-29].

Table 2. Adsorption parameters of SFGD.

\begin{tabular}{|c|c|c|c|c|c|c|c|c|}
\hline \multirow[t]{2}{*}{ Inhibitor } & \multirow[t]{2}{*}{$\begin{array}{c}T \\
\left({ }^{\circ} \mathbf{C}\right)\end{array}$} & \multicolumn{2}{|c|}{ Langmuir isotherm } & \multicolumn{2}{|c|}{$\begin{array}{l}\text { Freundlich } \\
\text { isotherm }\end{array}$} & \multicolumn{3}{|c|}{ Kinetics isotherm } \\
\hline & & $\begin{array}{c}K_{\mathbf{L}} \\
(\mathbf{L} / \mathbf{m l})\end{array}$ & $\begin{array}{c}\Delta G_{\mathrm{ads}}^{\mathbf{0}} \\
(\mathrm{kJ} / \mathrm{mol})\end{array}$ & $\begin{array}{c}K_{\mathbf{F}} \\
(\mathbf{L} / \mathbf{m l})\end{array}$ & $n^{\prime \prime}$ & $C_{i}(\mathrm{M})$ & $\operatorname{Ln} A$ & $\underset{(\mathrm{kJ} / \mathrm{mol})}{E_{\mathrm{a}}}$ \\
\hline \multirow{5}{*}{ SFGD } & & & & & & 0 & 3.18 & 138.50 \\
\hline & 30 & 0.0002 & -11.34 & 1.28 & 18.05 & 0.002 & 3.56 & 217.50 \\
\hline & 40 & 0.0003 & -10.65 & 1.24 & 16.56 & 0.004 & 3.69 & 249.86 \\
\hline & 50 & 0.0006 & -9.13 & 1.42 & 10.10 & 0.006 & 3.73 & 260.03 \\
\hline & 60 & 0.0008 & -8.62 & 1.39 & 8.33 & 0.008 & 3.76 & 270.10 \\
\hline
\end{tabular}

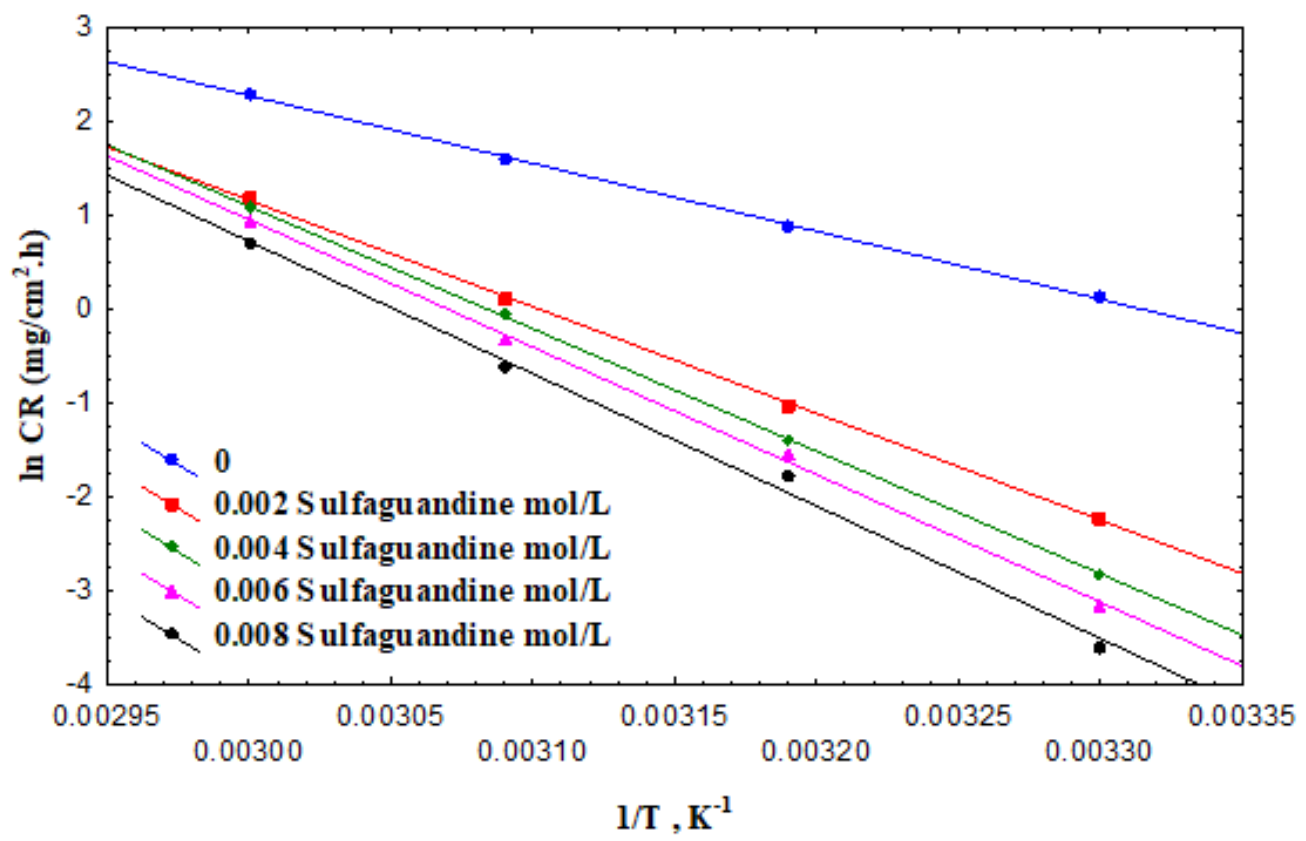

Figure 5. Arrhenius plot of carbon steel in hydrochloric acid containing various concentration of sulfaguanidine that effect on the corrosion rate at different temperature $\left(30-60^{\circ} \mathrm{C}\right)$. 


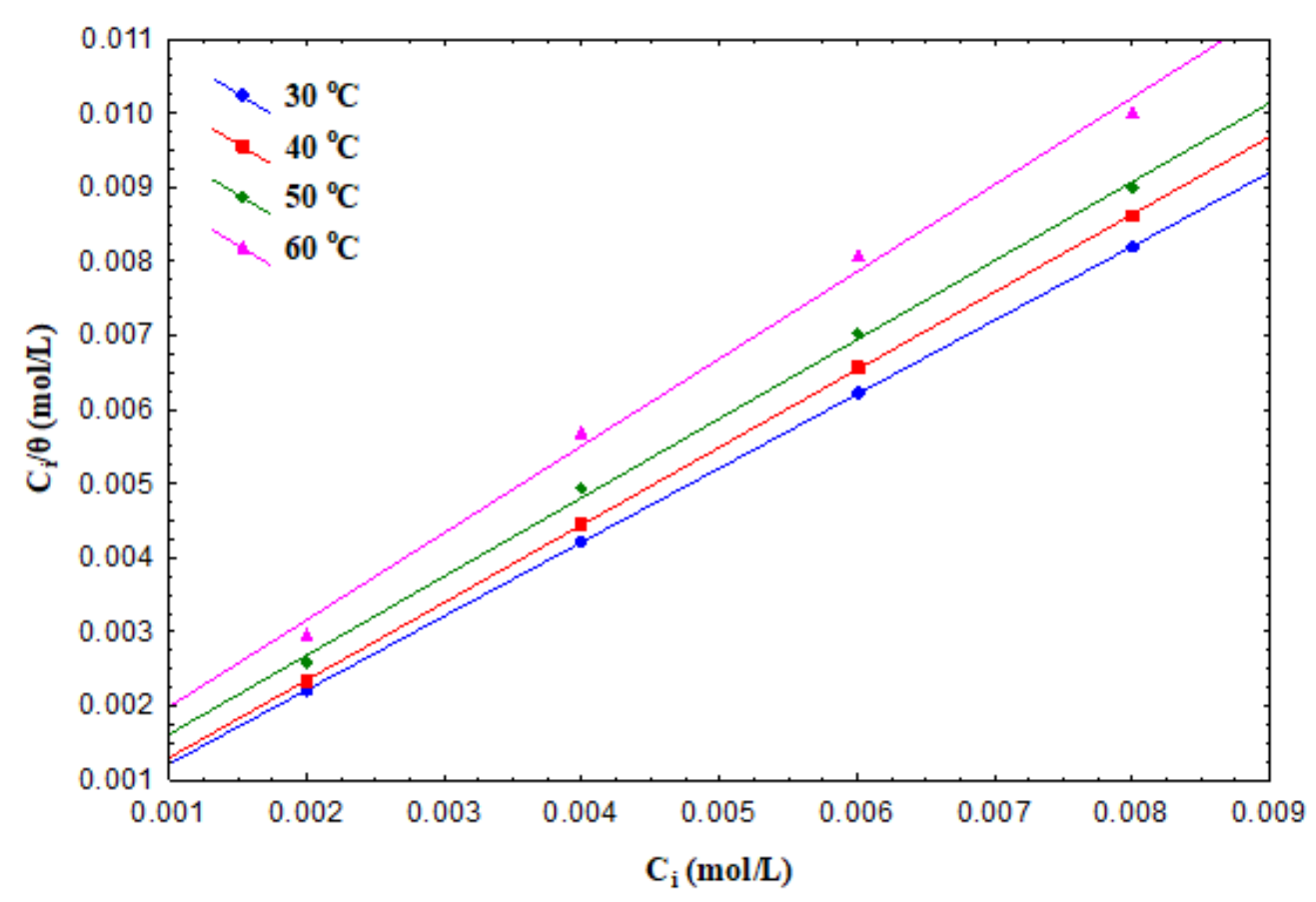

Figure 6. Langmuir adsorption isotherm of sulfaguanidine on the corrosion rate of carbon steel in hydrochloric acid at different temperature.

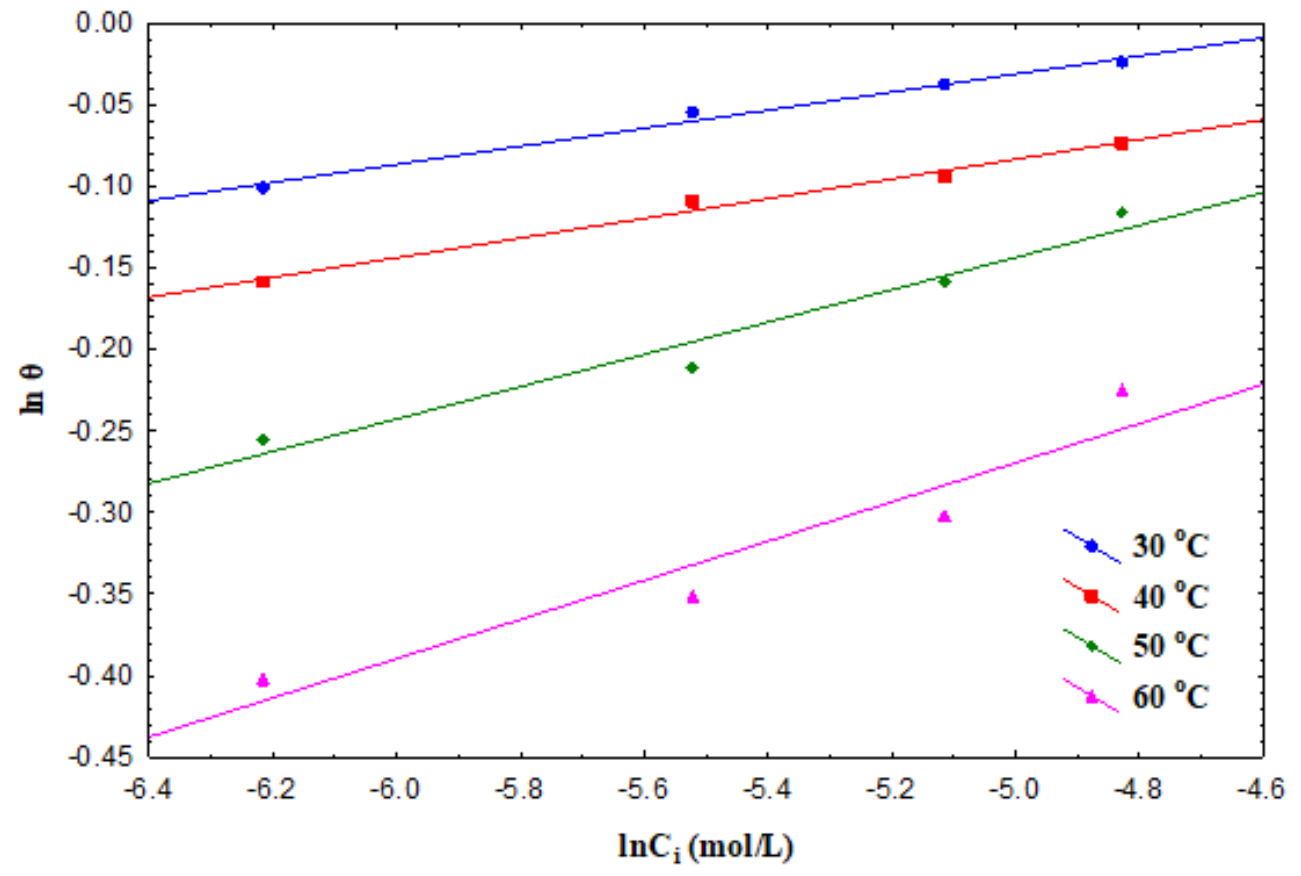

Figure 7. Freundligh adsorption isotherm of sulfaguanidine on the corrosion rate of carbon steel in hydrochloric acid at different temperature. 


\section{Conclusion}

The SFGD acts as efficient inhibitor for the corrosion of carbon steel which represent the sample used in present work in 3\% hydrochloric acid medium, which acts as corrosive solution. When inhibitor concentration increasing, the efficiency of process increases and with increasing of temperature, the efficiency of inhibition or process decreases, maximum process efficiency for SFGD hit $97.61 \%$ at the upper concentration value of $0.008 \mathrm{M}$ and temperature at $30^{\circ} \mathrm{C}$. The adsorption on the surface of metal (carbon steel) of inhibitor used in this research followed Langmuir adsorption isotherm. Inhibitors containing in their structural nitrogen, sulphur and oxygen atoms functional groups, aromaticity, the possible steric effects have been reported as efficient inhibitor of corrosion. These compounds can adsorb on the surface of sample made of carbon steel.

\section{References}

1. A.A. Mahmmod, M.H. Ismael, A.A. Fadhil and N.H. Kurshed, Int. J. Corros. Scale Inhib., 2019, 8, no. 2, 356-365. doi: 10.17675/2305-6894-2019-8-2-15

2. L. Afia, R. Salghi, L. Bammou, E. Bazzi, B. Hammouti, L. Bazzi and A. Bouyanzer, J. Saudi Chem. Soc., 2014, 18, 19-25. doi: 10.1016/j.jscs.2011.05.008

3. L. Afia, R. Salghi, A. Zarrouk, H. Zarrok, E.H. Bazzi, B. Hammouti and M. Zougagh, Trans. Indian Inst. Met., 2013, 66, 43-49.

4. L. Afia, R. Salghi, E.H. Bazzi, A. Zarrouk, B. Hammouti, M. Bouri, H. Zarrouk, L. Bazzi and L. Bammou, Res. Chem. Intermed., 2012, 38, 1707-1717. doi: 10.1007/s11164-012-0496-y

5. A. Anejjar, R. Salghi, A. Zarrouk, O. Benali, H. Zarrok, B. Hammouti and E.E. Ebenso, J. Assoc. Arab Univ. Basic Appl. Sci., 2014, 15, 21-27. doi: 10.1016/j.jaubas.2013.06.004

6. A. Anejjar, R. Salghi, A. Zarrouk, H. Zarrok, O. Benali, B. Hammouti, S.S. Al-Deyab, E. Benchat and R. Saddik, Res. Chem. Intermed., 2015, 41, 913-925. doi: 10.1007/s11164-013-1244-7

7. M.S. Al-Otaibi, A.M. Al-Mayouf, M. Khan, A.A. Mousa, S.A. Al-Mazroae and H.Z. Alkhathlan, Corrosion inhibitory action of some plant extracts on the corrosion of mild steel in acidic media, Arabian J. Chem., 2012, 1-7.

8. I.B. Obot, N.O. Obi-Egbedi and S.A. Umoren, Antifungal drugs as corrosion inhibitors for aluminium in $0.1 \mathrm{M} \mathrm{HCl}$, Corros. Sci., 2009, 51, no. 8, 1868-1875. doi: 10.1016/j.corsci.2009.05.017

9. M. Mihit, S. El Issami, M. Bouklah, L. Bazzi, B. Hammouti, E. Ait Addi and R. Salghi, The inhibited effect of some tetrazolic compounds towards the corrosion of brass in nitric acid solution, Appl. Surf. Sci., 2006, 252, no. 6, 2389-2395. doi: $\underline{10.1016 / j . a p s u s c .2005 .04 .009}$ 
10. S. El Issami, L. Bazzi, M. Mihit, B. Hammouti, S. Kertit, E. Ait Addi and R. Salghi, Triazolic compounds as corrosion inhibitors for copper in hydrochloric acid, Pigm. Resin Technol., 2007, 36, no. 3, 161-168. doi: 10.1108/03699420710749027

11. A.A. Khadom, A.S. Yaro and A.A.H. Kadhum, Adsorption mechanism of benzotriazole for corrosion inhibition of copper-nickel alloy in hydrochloric acid, $J$. Chil. Chem. Soc., 2010, 55, no. 1, 150-152. doi: 10.4067/S0717-97072010000100035

12. E.M. Sherif and Su-M. Park, Inhibition of copper corrosion in $3.0 \% \mathrm{NaCl}$ solution by N-phenyl-1,4-phenylenediamine, J. Electrochem. Soc., 2005, 152, no. 10, B428-B433. doi: $10.1149 / 1.2018254$

13. A. Yildirim and M. Cetin, Synthesis and evaluation of new long alkyl side chain acetamide, isoxazolidine and isoxazoline derivatives as corrosion inhibitors, Corros. Sci., 2008, 50, no. 1, 155-165. doi: 10.1016/j.corsci.2007.06.015

14. J.R.B. Thavamani, E. Rani and T. Jeyaraj, Inhibition of the corrosion of aluminium in alkaline medium by 1-(phenyl)-3-(2-hydroxy phenyl)-propenone in the presence of tetrabutylammonium bromide, Chem. Sin., 2012, 0, no. 6, 1358-1368.

15. A.A. Mahmmod, I.A. Kazarinov, A.A. Khadom and H.B. Mahood, Experimental and theoretical studies of mild steel corrosion inhibition in phosphoric acid using tetrazoles derivatives, J. Bio- Tribo-Corros., 2018, 4, no. 4, 58. doi: 10.1007/s40735-018-0171-y

16. D.N. Komov, A.A. Mahmmod, A.A. Matikenova, L.A. Isaicheva, A.P. Kriven'ko and I.A. Kazarinov, Effect of Tetrazolic Corrosion Inhibitors on the Corrosion and Electrochemical Behavior of Steel in Phosphoric Acidic Solutions (Vliyanie ingibitorov ryada tetrazolov na korrozionno-elektrokhimicheskoe povedenie stali v fosfornokislykh rastvorakh), Izvestiya Saratovskogo Universiteta. Novaya Seriya. Seriya: Khimiya. Biologiya. Ekologiya, 2014, 14, no. 2, 32-38 (in Russian).

17. K.F. Khaled, Adsorption and inhibitive properties of a new synthesized guanidine derivative on corrosion of copper in $0.5 \mathrm{M} \mathrm{H}_{2} \mathrm{SO}_{4}$, Appl. Surf. Sci., 2008, 255, 1811-1818. doi: $10.1016 /$ j.apsusc. 2008.06 .030

18. A. Popova, M. Christov and A. Zwetanova, Effect of the molecular structure on the inhibitor properties of azoles on mild steel corrosion in $1 \mathrm{M}$ hydrochloric acid, Corros. Sci., 2007, 49, no. 5, 2131-2143. doi: 10.1016/j.corsci.2006.10.021

19. R. Solmaz, G. Kardaş, B. Yazici and M. Erbil, Colloids Surf., A, 2008, 312, 7-17. doi: 10.1016/j.colsurfa.2007.06.035

20. M. Prajila, J. Sam, J. Bincy and J. Abraham, Electroanalytical studies on the interaction of 4-(N,N-dimethylaminobenzilidine)-3-mercapto-6-methyl-1, 2, 4-triazin (4H)-5-one (DAMMT) with mild steel in perchloric acid, J. Mater. Environ. Sci., 2012, 3, 10451064.

21. U.J. Naik, V.A. Panchal, A.S. Patel and N.K. Shah, The corrosion inhibition study of Al-Pure By $p$-Anisidine-N-Benzylidene Schiff base in $\mathrm{HCl}$ solution, J. Mater. Environ. Sci., 2012, 3, 935-946. 
22. M. Larouj, M. Belayachi， H. Zarrok， A. Zarrouk, A. Guenbour, M. Ebn Touhami, A. Shaim, S. Boukhriss, H. Oudda and B. Hammouti, Anticorrosive properties of 3hydroxy-7-isocyano-8-phenyl-2-(p-tolyl)pyrimido[2,1-b][1,3]thiazine-4,6-dione on carbon steel in 1.0 M HCl Solution, Pharma Chem., 2014, 6, no. 3, 373-384.

23. M. Larouj, H. Lgaz, H. Zarrok, H. Serrar, H. Zarrok, H. Bourazmi, A. Zarrouk, A. Elmidaoui, A. Guenbour, S. Boukhris and H. Oudda, J. Mater. Environ Sci., 2015, 6, no. 11, 3251-3267.

24. M. Larouj, M. Belkhaouda, H. Lgaz, R. Salghi, S. Jodeh, S. Samhan, H. Serrar, S. Boukhris, M. Zougagh and H. Oudda, Pharma Chem., 2016, 8, no. 2, 114-133.

25. H. Lgaz, O. Benali, R. Salghi, S. Jodeh, M. Larouj, O. Hamed, M. Messali, S. Samhan, M. Zougagh and H. Oudda, Pharma Chem., 2016, 8, no. 2, 172-190.

26. K.C. Emregul, R. Kurtaran and O. Atakol, An investigation of chloride-substituted Schiff bases as corrosion inhibitors for steel, Corros. Sci., 2003, 45, no. 12, 2803-2817. doi: 10.1016/S0010-938X(03)00103-3

27. A. Lalitha, S. Ramesh and S. Rajeswari, Surface protection of copper in acid medium by azoles and surfactants, Electrochim. Acta, 2005, 51, 47-55. doi: 10.1016/j.electacta.2005.04.003

28. A.S. Fouda, M. Abdallah and M. El-Hoseiny, Acrylonitrile derivatives as corrosion inhibitors for Cu10Ni alloy in $0.5 \mathrm{M}$ hydrochloric acid solution, Afr. J. Pure Appl. Chem., 2013, 7, 252-263.

29. S.A. Umoren and E.E. Ebenso, Mater. Chem. Phys., 2007, 106, 387-393. doi: $\underline{\text { 10.1016/j.matchemphys.2007.06.018 }}$ 